\title{
THE PROPERTY CHANGES OF AMMUNITION ELEMENTS DUE TO THE EXPLOITATION TIME
}

\section{ZMIANY WLAŚCIWOŚCI ELEMENTÓW AMUNICJI W CZASIE ICH EKSPLOATACJI}

\author{
Dariusz Ampuła \\ Military Institute of Armament Technology \\ e-mail:ampulad@witu.mil.pl
}

\begin{abstract}
The way carry out of analysis concerning correctness working of evaluation module proposed in functioning research methodology, chosen features elements of artillery fuses was presented in the article. Probability distributions of the aptitude time of tested ammunition elements were applied for verification of undertaken post diagnostic decisions. The analysis of test results chosen fuses elements, based on the standard normal distributions were executed, further the graphic interpretations of these distributions were made. A measurement of the strength of resistance decline of the side-bolt spring was chosen for the analysis, as a way of checking MG-37 and MG-57 fuse types features. Furthermore, the author presents an illustrative comparison of normal distributions, which confirms that post diagnostic decisions had been undertaken correctly. The graphic interpretations of analyzed test results of $M G$-37 fuse elements type were executed by means of two-parameters gamma distribution in the comparison. Concise conclusions confirming the correctness of functioning of evaluation module in the research methodology were introduced at the end of the article.
\end{abstract}

Keywords: normal distribution, feature, testing cycle, test, properties.

Streszczenie: $W$ artykule przedstawiono sposób przeprowadzenia analizy dotyczacej poprawności działania modulu ocenowego zaproponowanego $w$ funkcjonujacej metodyce badawczej, wybranych cech elementów zapalników artyleryjskich. Do weryfikacji podjętych decyzji podiagnostycznych, zastosowano rozktady prawdopodobieństwa czasu zdatności badanego elementu amunicji. Analizę wyników badań wybranych elementów zapalników, oparto na standardowych rozktadach normalnych $i$ wykonano interpretacje graficzne tych rozkładów. Do analizy wybrano pomiar sity spadku oporu sprężyny rygla bocznego jako sprawdzana ceche zapalników typu MG-37 i MG-57. Dodatkowo przedstawiono pogladowe zestawienie rozkładów normalnych z którego wynika, że podjęte decyzje podiagnostyczne byly prawidlowe. W celach porównawczych wykonano za pomoca dwuparametrowego rozkładu gamma interpretacje graficzne analizowanych wyników badań elementów zapalników typu MG-37. Na końcu artykutu przedstawiono zwięzłe wnioski, potwierdzające poprawność funkcjonowania modutu ocenowego w metodyce badawczej.

Stowa kluczowe: rozkład normalny, cecha, cykl badania, badanie, właściwości. 
The property changes of ammunition elements due to the exploitation time Zmiany właściwości elementów amunicji w czasie ich eksploatacji

\section{Introduction}

In the article the author undertakes an attempt to execute analysis of chosen features of elements tested artillery fuses, in regard to the proper operation of evaluation module proposed in functioning research methodology. Analyzed fuses are head fuses MG-37 and MG-57 types. The aim of this article is to show the lifetime also the same time the exploitation period of ammunition elements in terms of their statistical evaluation in consideration of undertaken post diagnostic decisions.

The head fuses applied in 37 - and in 57 - fragments-tracer cartridges were subjected of the analysis. The executed analysis includes all previous results of laboratory tests which were executed for chosen fuse lots. The presented test results define author's understandings of the life cycle of analyzed fuse lots.

Applied probability distributions the time of aptitude tested element of ammunition, to verification undertaken post diagnostic decisions on the basis conducted diagnostic tests. The carried out analysis is based on normal distribution, which is commonly applied in practical applications. The test result of MG-37 fuse element type were additionally interpreted by two-parameters gamma distribution.

\section{Normal distribution}

The normal distribution is unimodal and symmetrical in relations to the mean value, so expected value, median and modal value are equal, and all central moments of the odd line are equal zero. The distribution of random variable about normal distribution is called Laplace integral, and its values are given in tables in literature.

The evaluation way of chosen analyzed features tested elements of fuses are presented below. It was accepted that the time of proper work of tested ammunition elements can be approximately described by the normal distribution. We will search for determined probability of the definite random variable value will be acceptable from the given quantity range.

The normal distribution is completely determined by two basic parameters: the mean value and standard deviation. In order to approximate the way of determining mean value and standard deviation, the method of defining these quantity of the example fuse test in which basic parameter is measured during test is the strength of the resistance of the side bolt spring, was presented below.

\section{The analysis test results of chosen elements of fuses}

Laboratory test results samples coming from the stored fuses MG-57 type, 30-59-132 lot and fuses MG-37 type 10-54-132 lot were subjected of the analysis. Lots mentioned above were taken to this analysis intentionally. The first of them was tested in eight test cycles but the second only in three. The diagnostic tests of fuses were conducted in compliance with methodology binding to the end of 2010 year [1]. 
The aim of this analysis is to show natural aging processes in analyzed fuses and define the influence of these processes on their qualitative coefficients.

What is more, it is also to check if appointed safety cycles prediction for analyzed fuses types, were determined correctly. The result will be presented on comparison based with commonly applied in practical distributions: normal distribution and gamma distribution.

In this article, there only chosen tested fuses features were presented. These features show the possibility of their changes basing on storage time. This chosen feature will be the decline resisting of force springs applied in constructions MG-57 and MG-37 fuse types mentioned above. The both cases include the identical kind of the spring.

\section{The analysis test results fuses type MG-57}

In the case of MG-57 fuse type the chosen feature was measurement of strength of resistance decline of the side bolt spring part 18. Results of measurement shown in diagnostic test cards were presented in the table 1 for all test cycles. This feature was determined in cards as "W6" mark and it will be called identical in this article. In the next columns there are presented test results for the following eight test cycles of analyzed spring.

Measurements results showed in the table 1 present the values of measured resistance of this kind spring expressed in G unit (gram force). This is an old measure unit, but in the aim of clearance for all test results, it is still applied in our test cards. The next columns from 2 to 9 present obtained results of „W6” measured feature in test cycles from 1 to 8 . Blank spaces in the columns 5 to 7 testify that these springs were not tested.

By the help of software [2] histograms of the normal distributions, which presents calculated mean value $\mu$ and standard deviation $\sigma$ were crossed out. For analyzed spring range value of resisting strength of this spring remained adopted in which obtained results should be situated. This range in compliance with technical documentation contains between values $117 \div 166$ G. Received histograms for analyzed test results of the side bolt spring part 18 in all test cycles together with crossed out approximations of the normal distribution were placed on figures $1 \div 8$. In the next order the standardization of analyzed random variable was executed (lower and upper value applied denomination ). Obtained values were presented in the table 2 in columns 6 and 7. Then, from statistical tables the level distribution of standard normal distribution measures for these obtained standardization (column 8 and 9) were taken. At no. 1 and no. 8 test cycle for upper of analyzed range, entered measures 1,00 because values level of distribution for measures standardization above 5,00 are very close to this measure, practically we should have given the measure with precision to seven digits after comma. 
The property changes of ammunition elements due to the exploitation time Zmiany właściwości elementów amunicji w czasie ich eksploatacji

Table 1 - result measurements of feature ,W6” for 30-59-132 lot MG-57 fuses

\begin{tabular}{|c|c|c|c|c|c|c|c|c|}
\hline $\begin{array}{c}\text { No. } \\
\text { fuses }\end{array}$ & $\mathrm{W} 6 / 1$ & $\mathrm{~W} 6 / 2$ & $\mathrm{~W} 6 / 3$ & $\mathrm{~W} 6 / 4$ & $\mathrm{~W} 6 / 5$ & $\mathrm{~W} 6 / 6$ & $\mathrm{~W} 6 / 7$ & $\mathrm{~W} 6 / 8$ \\
\hline 1 & 2 & 3 & 4 & 5 & 6 & 7 & 8 & 9 \\
\hline 1 & 126 & 150 & 141 & 140 & 135 & 140 & 140 & 120 \\
\hline 2 & 133 & 145 & 145 & 150 & 135 & 125 & 130 & 140 \\
\hline 3 & 149 & 150 & 139 & 140 & 140 & 125 & 140 & 125 \\
\hline 4 & 133 & 150 & 150 & 145 & 135 & 140 & 135 & 125 \\
\hline 5 & 133 & 150 & 139 & 145 & 140 & 135 & 140 & 130 \\
\hline 6 & 132 & 155 & 150 & 150 & 130 & 140 & 130 & 125 \\
\hline 7 & 133 & 150 & 141 & 130 & 130 & 135 & 150 & 135 \\
\hline 8 & 137 & 150 & 141 & 140 & 135 & 130 & 135 & 110 \\
\hline 9 & 124 & 150 & 154 & 140 & 150 & 145 & 140 & 135 \\
\hline 10 & 132 & 160 & 150 & 140 & 130 & 140 & 140 & 130 \\
\hline 11 & 132 & 155 & 130 & 145 & 135 & 140 & 135 & 120 \\
\hline 12 & 132 & 150 & 140 & 135 & 135 & 145 & 140 & 125 \\
\hline 13 & 127 & 150 & 146 & 140 & 140 & 140 & 145 & 130 \\
\hline 14 & 135 & 150 & 144 & 140 & 140 & 135 & 140 & 125 \\
\hline 15 & 138 & 160 & 145 & 135 & 130 & 150 & 135 & 140 \\
\hline 16 & 129 & 145 & 140 & 155 & 140 & 135 & 145 & 130 \\
\hline 17 & 129 & 155 & 140 & 140 & 130 & 130 & 130 & 125 \\
\hline 18 & 132 & 150 & 140 & 145 & 145 & 135 & 140 & 130 \\
\hline 19 & 135 & 140 & 154 & - & 130 & 140 & 125 & 120 \\
\hline 20 & 123 & 145 & 150 & - & 120 & - & 150 & 125 \\
\hline
\end{tabular}

The similar situation is in the second test cycle for lower end of analyzed range, entered the value 0,00 , because distribution value level for measure below minus 5,00 is very close to the zero. To describe values of level distribution standardization normal distribution we used ready statistical tables [4]. In the column 11 there is the age of lot in which this fuse was tested. As it is visible from the information, this lot was tested in age between 14 and 46 storage age of its years. Received test results do not disqualify this fuses lot but on the contrary, the tested lot is still safe in the storage and reliable in working that is testified by estimated value of nominal probability.

At this point we should remember, that if value of standardization is negative measure then we should apply dependence (1) to describe measure of the distribution level of standardization normal distribution.

$$
F(-u)=1-F(u)
$$

where: $F$ - distribution level function value of standardization normal distribution, $u$ - analyzed measure.

Estimated values of nominal probability (column 10) was executed on the end. 
From obtained results it is visible that practically on the space of many years storage this type of fuses, the value of nominal probability is very high, practically close to the value one. Only in 46 - year - old fuses value slightly falls to 0,924 , however it is still high and undertaken post diagnostic decision „B3" that is to test after three - years storage cycle, was a correct decision.

Table 2 - results of calculations for analyzed spring 30-59-132 lot MG-57 fuses

\begin{tabular}{|c|c|c|c|c|c|c|c|c|c|c|}
\hline 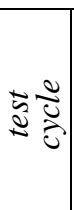 & 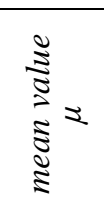 & 。 & 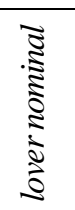 & 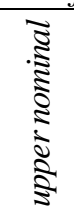 & 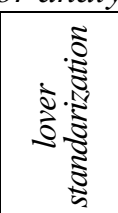 & 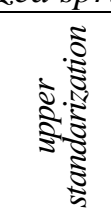 & 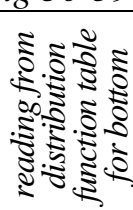 & 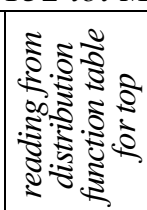 & 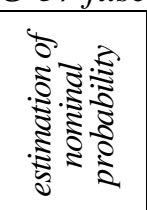 & 8 \\
\hline 1 & 2 & 3 & 4 & 5 & 6 & 7 & 8 & 9 & 10 & 11 \\
\hline 1 & 132,20 & 5,5970 & 117 & 166 & $-2,7157$ & 6,0389 & 0,00326 & 1,00000 & 0,99674 & 14 \\
\hline 2 & 150,50 & 4,8395 & 117 & 166 & $-6,9222$ & 3,2028 & 0,00000 & 0,99931 & 0,99931 & 19 \\
\hline 3 & 143,95 & 6,0129 & 117 & 166 & $-4,4820$ & 3,6671 & 0,00001 & 0,99988 & 0,99987 & 25 \\
\hline 4 & 141,94 & 5,9752 & 117 & 166 & $-4,1739$ & 4,0266 & 0,00002 & 0,99997 & 0,99995 & 29 \\
\hline 5 & 135,25 & 6,5845 & 117 & 166 & $-2,7717$ & 4,6701 & 0,00280 & 0,999998 & 0,997198 & 34 \\
\hline 6 & 137,11 & 6,5226 & 117 & 166 & $-3,0831$ & 4,4292 & 0,00104 & 0,999995 & 0,998955 & 38 \\
\hline 7 & 138,25 & 6,5444 & 117 & 166 & $-3,2403$ & 4,2403 & 0,00058 & 0,99998 & 0,99940 & 42 \\
\hline 8 & 127,25 & 7,1789 & 117 & 166 & $-1,4278$ & 5,3978 & 0,07636 & 1,00000 & 0,92364 & 46 \\
\hline
\end{tabular}

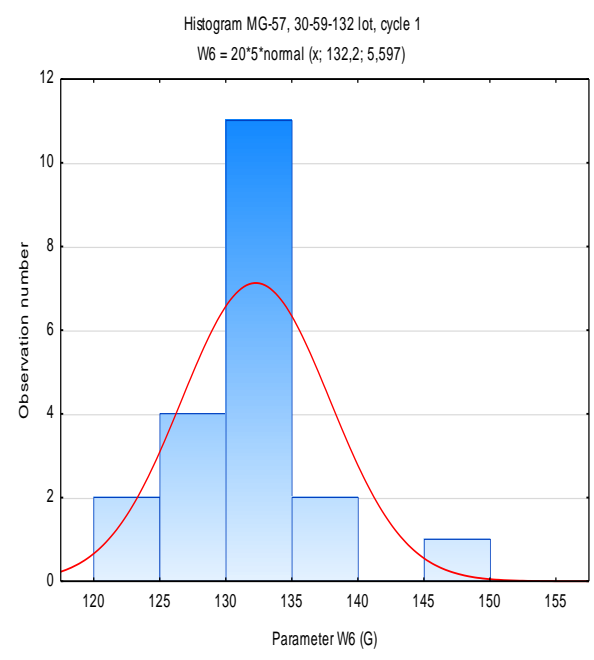

Fig.1 Histogram of first cycle tested spring MG-57 fuse 30-59-132 lot together with curve graph of normal distribution.

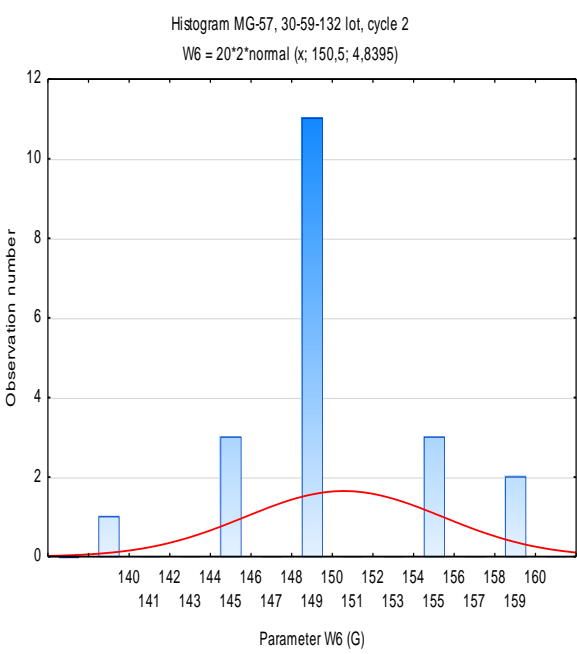

Fig.2 Histogram of second cycle tested spring MG-57 fuse 30-59-132 lot together with curve graph of normal distribution. 
The property changes of ammunition elements due to the exploitation time Zmiany wtaściwości elementów amunicji w czasie ich eksploatacji

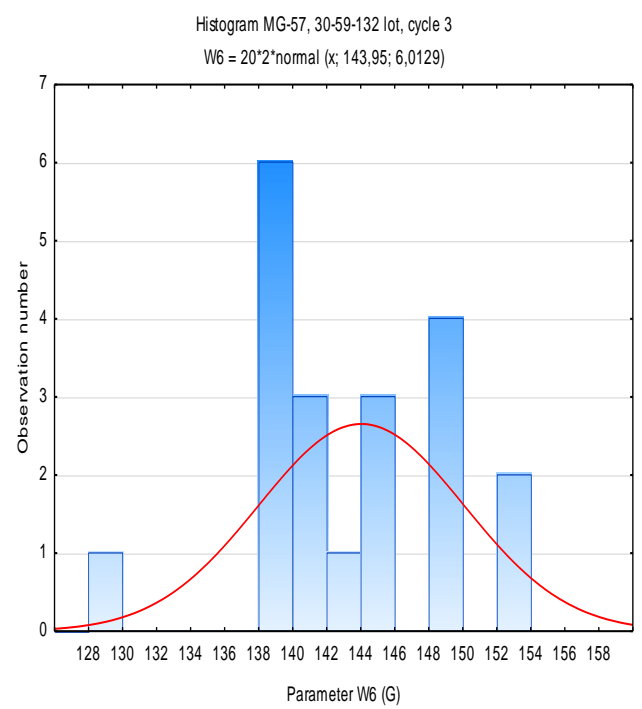

Fig.3 Histogram of thrid cycle tested spring MG-57 fuse 30-59-132 lot together with curve graph of normal distribution.

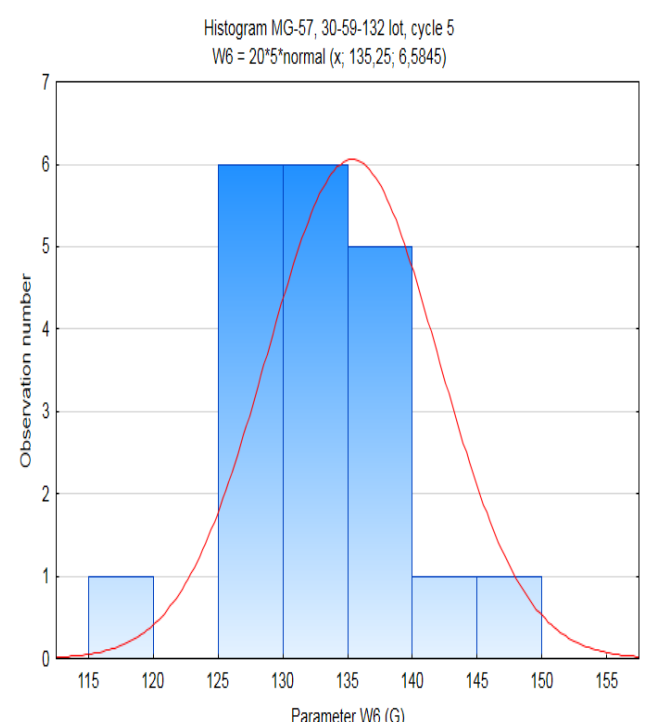

Fig.5 Histogram of fifth cycle tested spring MG-57 fuse 30-59-132 lot together with curve graph of normal distribution.
Histogram MG-57, 30-59-132 lot, cycle 4

W6 $=18^{*} 2^{*}$ normal $(x ; 141,9444 ; 5,9752)$

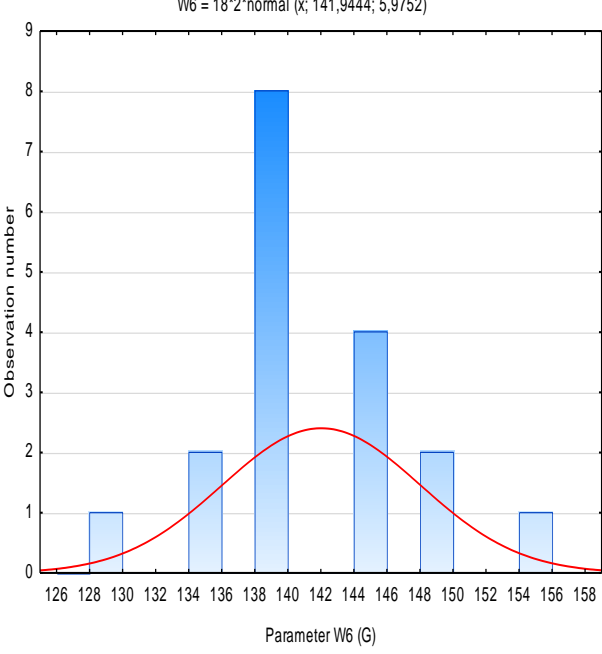

Fig.4 Histogram of fourth cycle tested spring MG-57 fuse 30-59-132 lot together with curve graph of normal distribution.

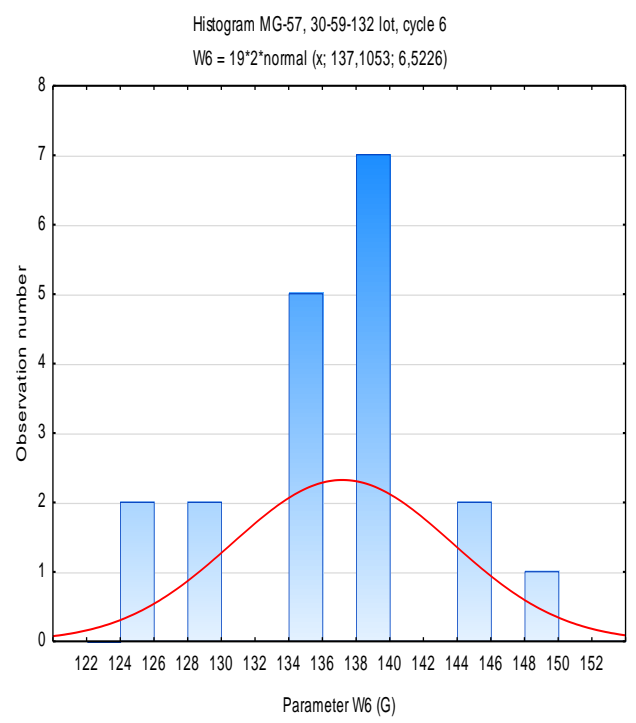

Fig.6 Histogram of sixth cycle tested spring MG-57 fuse 30-59-132 lot together with curve graph of normal distribution. 


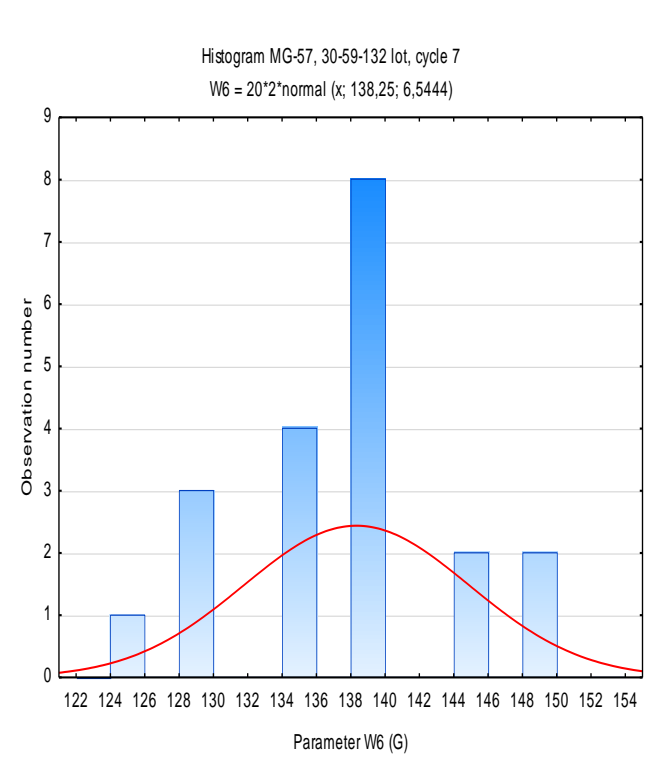

Fig.7 Histogram of seventh cycle tested spring MG-57 fuse 30-59-132 lot together with curve graph of normal distribution.

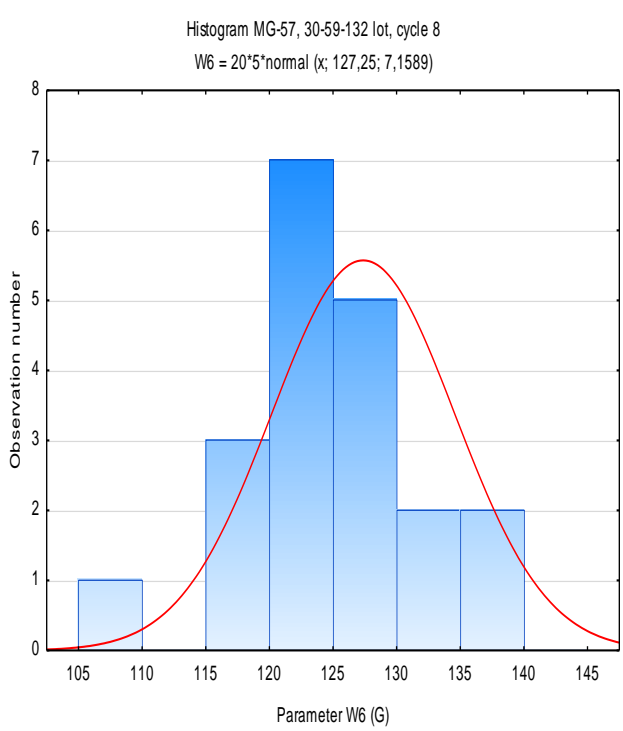

Fig.8 Histogram of eight cycle tested spring MG-57 fuse 30-59-132 lot together with curve graph of normal distribution.

\section{The analysis test results MG-37 fuses type}

In the case of MG-37 fuses type a chosen feature was also the measurement of the strength of resistance decline of side bolt spring part 18. In this type of fuses this kind of spring also appear. Intentionally different type of fuse was chosen to show, if this way of analysis can apply also in different kinds of fuses. Result of the measurement which are in the diagnostic test cards, for all test cycles, were presented in the table 3. This feature was defined in the cards also as "W6" mark. In the next columns $2 \div 4$ were introduced test results for next three test cycles analyzed spring, because this MG-37 fuse lot was tested only in three test cycles.

Results presented in the table 3of measurement show values of measured resistance strength of this kind spring expressed in $\mathrm{G}$ unit (gramma force). For introduced test results were also crossed by software [2] histograms normal distribution, which contain calculated mean values and standard deviation. Analyzed spring has the same range of nominal values of its resistance strength, carrying out from $117 \mathrm{G}$ to 166 G. Received histograms for analyzed test results side bolt spring part 18 in all test cycles together with curves of normal distribution were placed on figures $9 \div 11$. In the next order standardization of nominal values of analyzed spring was executed and taken from statistical table values of distribution function level 
The property changes of ammunition elements due to the exploitation time Zmiany właściwości elementów amunicji w czasie ich eksploatacji

standardization normal distribution. Obtained values were presented in the table 4 . At the end of 11 column, age of the lot in the test moment were given. As it is visible, this lot was tested at 21, 26 and 42 storage years.

Table 3 - results of measurements feature „W6" 10-54-132 lot MG-37 fuses

\begin{tabular}{|c|c|c|c|}
\hline No. fuse & W6/1 & $\mathrm{W} 6 / 2$ & W6/3 \\
\hline 1 & 2 & 3 & 4 \\
\hline 1 & 160 & 155 & 110 \\
\hline 2 & 125 & 150 & 145 \\
\hline 3 & 154 & 153 & 145 \\
\hline 4 & 140 & 150 & 100 \\
\hline 5 & 155 & 143 & 125 \\
\hline 6 & 130 & 160 & 110 \\
\hline 7 & 130 & 160 & 150 \\
\hline 8 & 160 & 150 & 140 \\
\hline 9 & 152 & 145 & 140 \\
\hline 10 & 155 & 155 & 115 \\
\hline 11 & 140 & 159 & 150 \\
\hline 12 & 150 & 160 & 115 \\
\hline 13 & 170 & 156 & 140 \\
\hline 14 & 145 & 153 & 155 \\
\hline 15 & 155 & 159 & 160 \\
\hline 16 & 150 & 149 & 150 \\
\hline 17 & 125 & 159 & 155 \\
\hline 18 & 160 & 150 & 135 \\
\hline 19 & 140 & 142 & 110 \\
\hline 20 & 135 & 162 & 130 \\
\hline
\end{tabular}


Table 4 - results of calculations for analyzed spring 10-54-132 lot MG-37 fuses

\begin{tabular}{|c|c|c|c|c|c|c|c|c|c|c|}
\hline 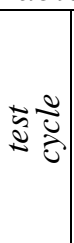 & 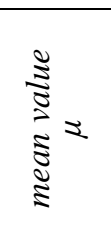 & 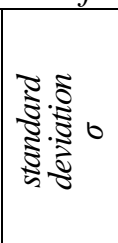 & 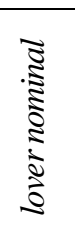 & 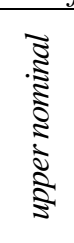 & 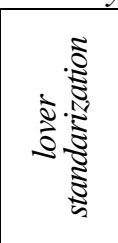 & 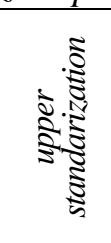 & 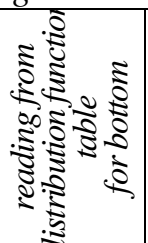 & 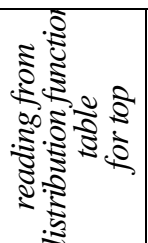 & 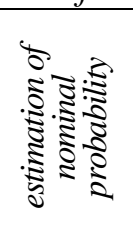 & 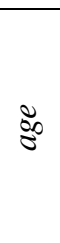 \\
\hline 1 & 2 & 3 & 4 & 5 & 6 & 7 & $=8$ & $=9$ & 10 & 11 \\
\hline 1 & 146,55 & 12,890 & 117 & 166 & $-2,2925$ & 1,5089 & 0,01101 & 0,93448 & 0,92347 & 21 \\
\hline 2 & 153,50 & 6,0044 & 117 & 166 & $-6,0789$ & 2,0818 & 0,0000 & 0,98124 & 0,98124 & 26 \\
\hline 3 & 134,00 & 18,324 & 117 & 166 & 0,9277 & 1,7463 & 0,17620 & 0,95994 & 0,78374 & 42 \\
\hline
\end{tabular}

Received test results, in particularly estimated value of nominal probability for storage age carrying out 42 years, indicates the fact probability value has significantly decreased. Results from working parameters foresee for this kind of tested spring dropped to the level which cannot be accepted by ammunition users. In the evaluation of the author of this article this lot of ammunition should be subjected of average repair so called, based on relying on exchange module which does not fulfill requirements of the user. In this case fuses tested lot 10-54-132 should have been exchange in this ammunition and withdraw from the exploitation. The decision regarding whether further way of utilization or usage MG-37 fuse lot belongs to gestor's of ammunition. Received value of evaluation nominal probability is tied in with undertaken decision based on evaluation module elaborated in the test methodology [1]. In compliance with this module undertake negative decision „W" that is withdraw from exploitation of this fuses lot, on grounds of inconsistencies detected during diagnostic test, which disqualified this lot from further its using.

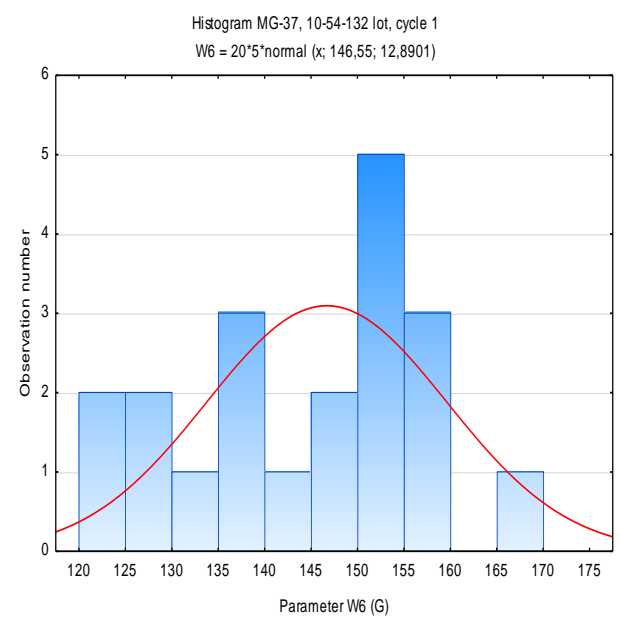

Fig.9 Histogram of first cycle tested spring MG-37 fuse 10-54-132 lot together with curve graph of normal distribution.

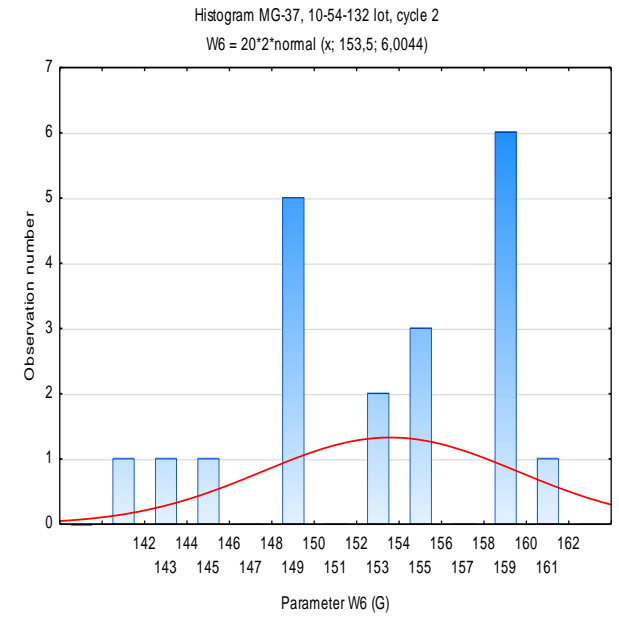

Fig.10 Histogram of second cycle tested spring MG-37 fuse 10-54-132 lot together with curve graph of normal distribution. 


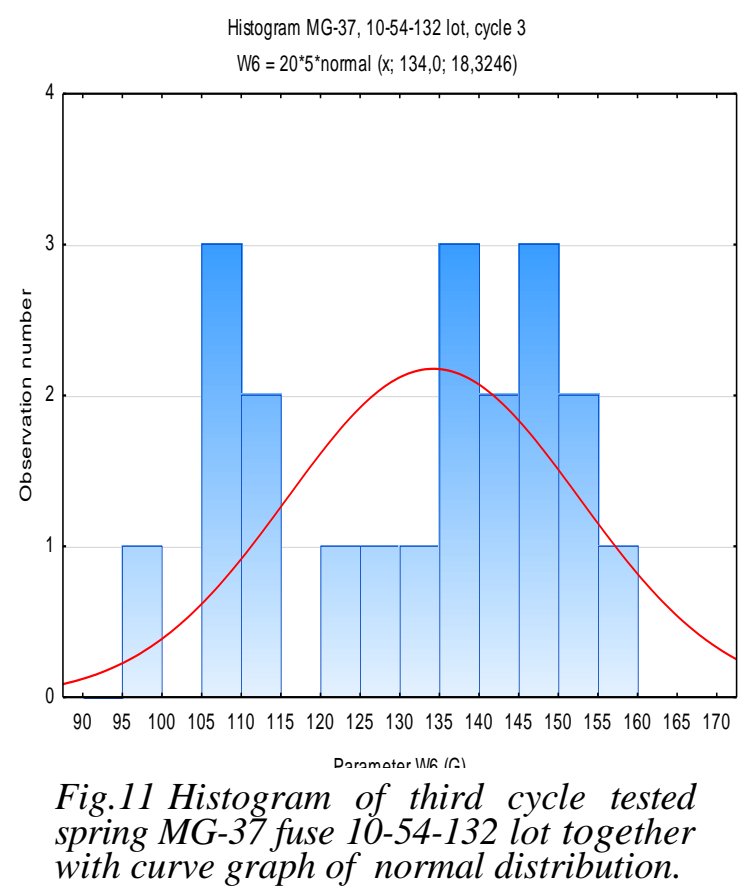

\section{The synthesis conducted analysis of test results}

For received results of analysis, based on their estimation by the help of standardization normal distribution we can execute an illustrative comparison of these distributions on the one figure. In consideration of the fact that in case of MG-57 fuses, were as eight test cycles, the execute of such comparison will be very troublesome. Only comparison normal distributions for the second case that is for MG-37 fuses was executed. Illustrative comparison of these distributions is presented on figure 15.

From this comparison results of the third test cycle it is visible that the curve of the normal distribution moved in to area of unacceptable sizes that is outside the interruption line marked on this figure, carrying out value 105,3 G. From this fact results the necessity definition negative prediction range in consideration of the declare moved curve of normal distribution that is undertaken negative post diagnostic decision.

Applied to evaluation test results of normal distribution are not only a distribution which can be used for this purpose. The next can be for example the simplest from gamma distribution named two-parameter gamma distribution. It is very useful in statistical test. Scale parameter and shape parameter belong to parameters of this gamma distribution. 
On figures $12 \div 14$ the graphic interpretations tested feature MG-37 fuse that is sidebolt spring part 18 were presented. Intentionally executed these graphic interpretation for the same fuse, so that the reader is able to see how slightly are the differences during application gamma distribution to evaluation analyzed features tested fuses. Of course to evaluation tested ammunition elements we can also apply other probability distributions such as logarithmic - normal distribution or exponential distribution, however presented in article probability distributions are suitable to this purpose superlatively. Particularly normal distribution is this kind of distribution, which is universal distribution is applied most often in statistics.

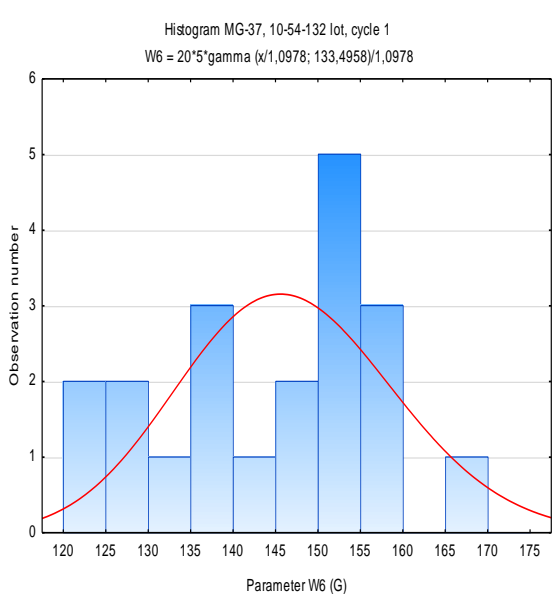

Fig.12 Histogram of first cycle tested spring MG-37 fuse 10-54-132 lot together with curve graph of normal distribution.

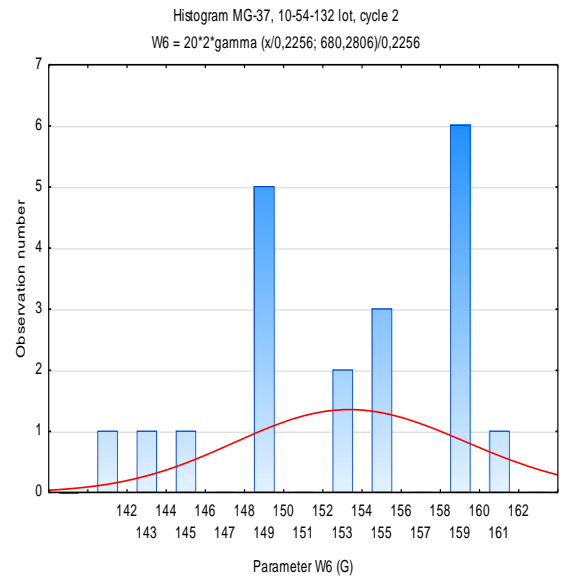

Fig.13 Histogram of second cycle tested spring MG-37 fuse 10-54-132 lot together with curve graph of normal distribution.

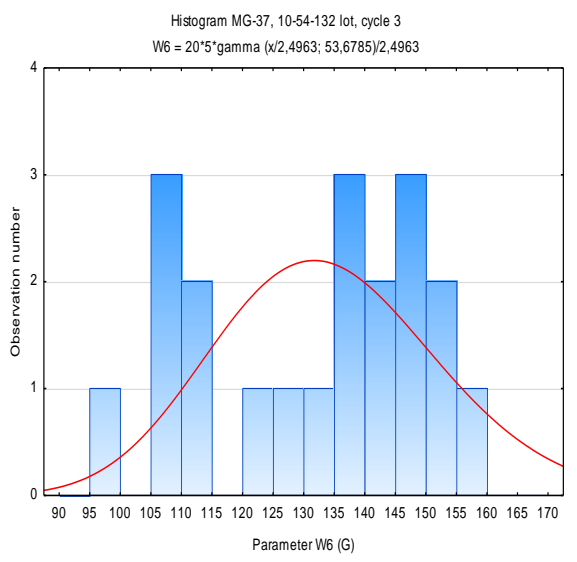

Fig.14 Histogram of third cycle tested spring MG-37 fuse 10-54-132 lot together with curve graph of normal distribution. 


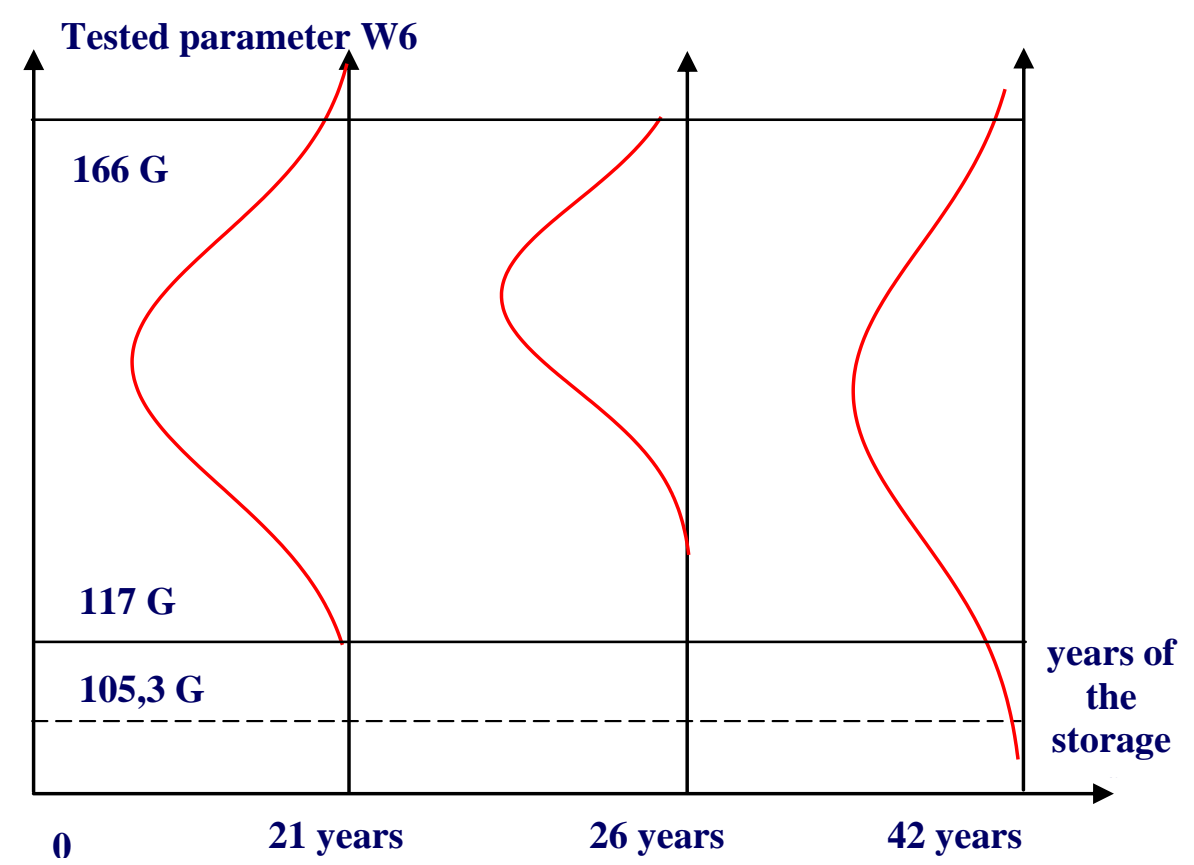

Fig. 15 Illustrative comparison curves of normal distribution for tested parameter spring MG-37 fuse 10-54-132 lot.

\section{Conclusions}

The way of checking correctness of undertaken post diagnostic decisions on the example elements of MG-37 and MG-57 artillery fuse types were presented in this article. The purpose of this article was show a simple control method which based on probability distributions. Introduced in this case normal distribution is one of many which can be applied to checking correctness of used prediction evaluations. As it is visible from presented analysis of test results of the chosen feature of tested spring, applied method of verification of correctness introduced prediction ranges for tested fuses, confirmed undertaken post diagnostic decision. Obtained probability distributions after executed their standardization and definition value distribution function for adopted and applied in tests nominal measures of sag analyzed spring in MG-57 and MG-37 fuse types, showed the correctness of functioning evaluation module in the applied tests methodology.

Presented way of analysis can be applied to every kind of tested element feature for ammunition. It can be for example measured values times of destructor working in fuses and also values of humidity or caloricity powder applied in propelling charges for individual kinds of cartridges exploited in Polish Army. 
This method practically can be applied in every type of ammunition where result of test is define obtained measuring value during carried out diagnostic tests.

The showed method of the analysis test results defined ammunition element feature we can interpret as complete cycle of its life to moment of diagnostic check. Such analysis is defined of the life cycle for specific tested element, we can execute for all elements in define time their life that is in define time their long - storage in military resources based on of course about obtained current test results defined feature chosen ammunition elements.

\section{References}

[1] Praca zbiorowa - Metodyka badań diagnostycznych amunicji - Indeks N5001b - 1985r. Archiwum WITU;

[2] Statystyka 10 - Statsoft Polska 2010 r. - oprogramowanie komputerowe;

[3] Karty badań środków bojowych - Archiwum WITU;

[4] W. Starzyńska - Statystyka praktyczna - Wydawnictwo PWN, Warszawa $2005 \mathrm{r}$.

[5] A. Luszniewicz, T. Słaby - Statystyka z pakietem komputerowym Statisica Wydawnictwo C.H. Beck, Warszawa 2003 r.

[6] D. Ampuła - Parametryczny system oceny magazynowanej amunicji Rozprawa doktorska, ITWL Warszawa 2006 r.

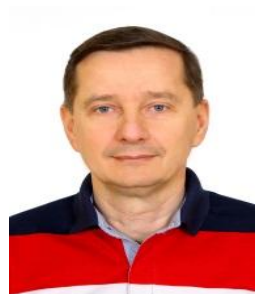

D. Sc. Eng. Dariusz Ampula, graduated Military Technical Academy in the area of the Ground Armament Systems. He became the scientifically - test worker at Military Institute of Armament Technology in Zielonka after holding of one year professional practice. The degree scientific of doctor he obtained in 2006 in Air Force Institute of Technology. The author and co-author of works from the area technical diagnostics and reliability of working land ammunition. In his analytical analysis he focuses on the problems of prediction process tested elements of land ammunition. 
The property changes of ammunition elements due to the exploitation time Zmiany wtaściwości elementów amunicji w czasie ich eksploatacji 